\title{
DGAT1 mutations leading to delayed chronic diarrhoea: a case report
}

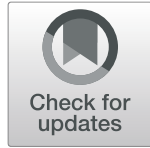

Luojia Xu', Weizhong $\mathrm{Gu}^{2}$, Youyou Luo ${ }^{1}$, Jingan Lou ${ }^{1}$ and Jie Chen ${ }^{1 *}$ (D)

\begin{abstract}
Background: Early-onset chronic diarrhoea often indicates a congenital disorder. Mutation in diacylglycerol oacyltransferase 1 (DGAT1) has recently been linked to early-onset chronic diarrhoea. To date, only a few cases of DGAT1 deficiency have been reported. Diarrhoea in those cases was severe and developed in the neonatal period or within 2 months after birth.

Case presentation: Here, we report a female patient with DGAT1 mutations with delayed-onset chronic diarrhoea. The patient had vomiting, hypoalbuminemia, hypertriglyceridemia, and failure to thrive at early infancy. Her intractable chronic diarrhoea occurred until she was 8 months of age. A compound heterozygous DGAT1 mutation was found in the patient, which was first found in the Chinese population. Her symptoms and nutrition status improved after nutritional therapy, including a fat restriction diet.
\end{abstract}

Conclusions: This case expanded our knowledge of the clinical features of patients with DGAT1 mutations. Intractable diarrhoea with delayed onset could also be a congenital disorder.

Keywords: Infantile diarrhoea, Failure to thrive, Genetics, Diacylglycerol o-acyltransferase, Case report

\section{Background}

Chronic diarrhoea is defined as diarrhoea lasting longer than 2 weeks [1]. The aetiology of chronic diarrhoea varies [1]. A group of chronic diarrhoea disorders may occur in early infancy and can be termed "congenital diarrhoea" [1]. Many patients with disorders in this group are affected by monogenic disorders that primarily affect the intestinal epithelium or secondarily affect intestinal epithelial function [1]. With the increasing use of next-generation sequencing in clinical practice, many monogenic disorders that cause chronic diarrhoea have been revealed. One of these monogenic disorders is caused by a mutation in the diacylglycerol o-acyltransferase 1 (DGAT1) gene (MIM \#: 604900). The DGAT1 gene encodes diacylglycerol o-

\footnotetext{
* Correspondence: 6185020@zju.edu.cn.

'Present Address: Department of Gastroenterology, Children's Hospital, Zhejiang University School of Medicine, National Clinical Research Center for Child Health, No.3333, Binsheng Road, Hangzhou, Zhejiang Province, PR China

Full list of author information is available at the end of the article
}

acyltransferase 1 (DGAT1), which is a microsomal enzyme with high expression in the small intestine, adrenal cortex, adrenal medulla, and testes [2]. DGAT1 and its isozyme DGAT2 catalyse the final step in triglyceride (TG) synthesis by using diacylglycerol (DAG) and fatty acyl CoA in humans [3] and help to absorb TGs in the small intestine [2]. However, in humans, only DGAT1 is highly expressed in the intestine [4].

Recent studies have shown that DGAT1 mutation is linked to chronic and severe diarrhoea that mostly develops in the neonatal period [4-7] or within 2 months after birth $[7,8]$. Herein, we report a female patient who had delayed-onset chronic diarrhoea with a compound heterozygous DGAT1 mutation, which, to our knowledge, has not been previously reported.

\section{Case presentation}

The patient was a girl born at 41 weeks gestation with spontaneous labour. Her birth weight was $3.3 \mathrm{~kg}$, and her length was $51.0 \mathrm{~cm}$. Her mother denied any prenatal

(c) The Author(s). 2020 Open Access This article is licensed under a Creative Commons Attribution 4.0 International License which permits use, sharing, adaptation, distribution and reproduction in any medium or format, as long as you give appropriate credit to the original author(s) and the source, provide a link to the Creative Commons licence, and indicate if changes were made. The images or other third party material in this article are included in the article's Creative Commons licence, unless indicated otherwise in a credit line to the material. If material is not included in the article's Creative Commons licence and your intended use is not permitted by statutory regulation or exceeds the permitted use, you will need to obtain permission directly from the copyright holder. To view a copy of this licence, visit http://creativecommons.org/licenses/by/4.0/. The Creative Commons Public Domain Dedication waiver (http://creativecommons.org/publicdomain/zero/1.0/) applies to the data made available in this article, unless otherwise stated in a credit line to the data. 
events. She came from a non-consanguineous Chinese family, and she was the first child without any siblings. She presented vomiting soon after birth but with normal stool output. The physical examination showed dehydration, but the rest of the examination was unremarkable. Her serum albumin and TG were in the normal range when she was 22 days old. She presented recurrent hypoalbuminemia and hypertriglyceridemia with a serum TG level of $8.34 \mathrm{mmol} / \mathrm{L}$ (normal range is $<1.70 \mathrm{mmol} /$ L) and normal cholesterol since she was 34 days old. She began to have several episodes of watery diarrhoea daily when she was 8 months old. She was breastfed after birth and then changed to an amino acid-based formula or extensively hydrolysed-based formula because of a suspected cow's milk protein allergy. Her routine stool test was normal, with negative results for viruses, bacteria, or parasites. In other laboratory results, immunoglobins decreased (IgG $0.96 \mathrm{~g} / \mathrm{L}$, IgA $0.15 \mathrm{~g} / \mathrm{L}$, IgM 0.32 $\mathrm{g} / \mathrm{L}$ ), and abnormalities were also revealed in the $\mathrm{T}$ and B cell subset analysis (CD20 14.22\%, CD3 65.44\%, CD4 20.56\%, CD8 34.90\%, NK cell 6.55\%, CD4/CD8 0.59). Prealbumin and IgE levels were unremarkable most of the time. Her iron level was $5.51 \mathrm{mmol} / \mathrm{L}$ (normal range 6.63-11.82 $\mathrm{mmol} / \mathrm{L}$ ), which was slightly low, but zinc, magnesium, and copper levels were all within a normal range. Retinol-binding protein was lower at $19.40 \mathrm{mg} / \mathrm{L}$ (normal range: $22-53 \mathrm{mg} / \mathrm{L}$ ), while vitamin $\mathrm{D}$, vitamin B12, and folic acid levels were normal. Insulin-like growth factor-1 (IGF-1) was $<25.0 \mathrm{ng} / \mathrm{ml}$ (normal range $51.0-303.0 \mathrm{ng} / \mathrm{ml}$ ), and insulin-like growth factor binding protein-3 (IGFBP-3) was $0.7 \mu \mathrm{g} / \mathrm{ml}$ (normal range $0.8-3.9 \mu \mathrm{g} / \mathrm{ml})$. The upper gastrointestinal contrast study showed nothing but a gastroesophageal reflex. Oesophagogastroduodenoscopy with biopsy was performed, which showed slightly flat villi in the descending duodenum, and pathology results demonstrated slight inflammation at the gastric antrum mucosa and chronic mucosal inflammation in the descending part of the duodenum. A percutaneous endoscopic gastrostomy and a percutaneous endoscopic transgastric jejunostomy were performed during the whole treatment course. She was given either an amino acid-based formula or extensively hydrolysed-based formula using gastrostomy tube feeding or jejunal tube feeding. Because of poor feeding with ongoing loss from the gastrointestinal tract, parenteral nutrition was added. She was on parenteral nutrition for approximately 11 months with an interruption for catheter-related infection, thrombosis, or discharge against doctor's orders. She had several episodes of bacterial or viral infections. Her parenteral nutrition provided a total energy of $71.4-153.5 \mathrm{kcal} / \mathrm{kg}$ daily with an amino acid supply of $2.5-3.5 \mathrm{~g} / \mathrm{kg}$ daily, and she could tolerate a maximum dose of $3.8 \mathrm{~g} / \mathrm{kg} / \mathrm{d}$ lipid emulsion (including $2.0 \mathrm{~g} / \mathrm{kg} / \mathrm{d}$ medium-chain triglyceride/long- chain triglyceride fat emulsion and $1.8 \mathrm{~g} / \mathrm{kg} / \mathrm{d} \omega-3$ fishoil lipid emulsion) without TG elevation or parenteral nutrition-associated cholestasis. She also received albumin, intravenous immune globulin infusion, and red blood cell transfusion when moderate anaemia occurred. When her feeding volume was decreased or she was put on nothing by mouth, her symptoms improved temporarily, and vice versa. Even then, she still suffered from a failure to thrive during hospitalization. Weight-for-age z-score (WAZ), length/height-for-age z-score (HAZ) and weight-for-length $\mathrm{z}$-score (WHZ) were calculated by WHO Anthro software (version 3.2.2). Her WAZ and WHZ were always below -3 . She was accidentally fed with rice porridge for a couple of days, and her symptoms were relieved when she was 16 months old. After her parents provided the consents, the whole-exome sequencing (WES) of peripheral blood from the proband was performed, and the Sanger sequencing was performed with her parents' peripheral blood to confirm whether they had the same mutations as the proband.

WES was performed as described previously [9]. The analysis results showed that our patient had compound heterozygous mutations in DGAT1: a paternally inherited splicing mutation at chr8: 145541376 c.895-1G > A and a maternally inherited splicing mutation at chr8: 145541757 c. $751+1 \mathrm{G}>$ C. The Sanger sequencing results are shown in Fig. 1. Her father and mother were heterozygous for each mutation.

The two mutations were both splicing mutations and could affect the results of transcription and translation. The analysis from the gnomAD database (gnomad. broadinstitute.org) showed that the mutation at chr8: 145541376 , c.895-1G > A was only reported in nonFinnish European populations with $1 / 251026$ in total allele counts [10]. The other mutation was not previously reported in the gnomAD database. Use of GERP++ [11] suggested that the mutations were conserved. In addition, use of MutationTaster (http://www.mutationtaster.org) [12] to test the potential pathogenicity of these mutations revealed that they were disease-causing. Human Splicing Finder (http://www.umd.be/HSF/) [13] showed that these two mutations most likely affected splicing.

DGAT1 protein expression in enterocytes was assessed by immunohistochemistry (IHC) staining in the biopsy tissue. IHC processing followed the instructions and is described in Additional file 1. DGAT1 protein expression in the gastric antrum (Fig. 2a) and duodenum (Fig. $2 \mathrm{~b}$ and $\mathrm{c}$ ) of the proband was shown in Fig. 2. Additional figures of the IHC results in the duodenum can be seen in Additional file 2.

The proband was confirmed with a diagnosis of DGAT1 deficiency. As a result, she moved to a fatrestricted diet. She started with rice porridge and rice 


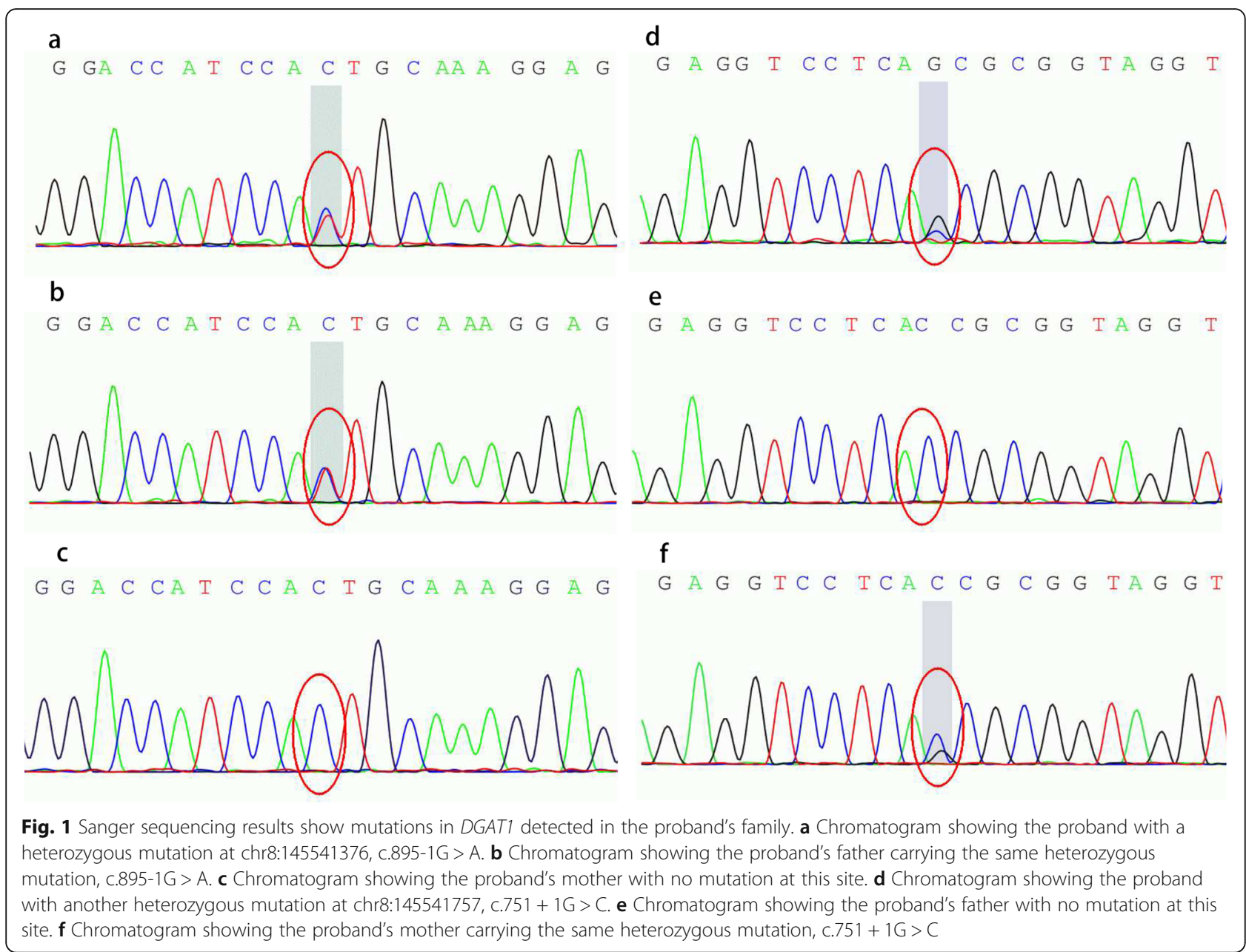

cereal, which were mainly carbohydrates. Lean meat and vegetables were introduced later as complementary feeding of semisolid foods. She did well without diarrhoea or vomiting. Finally, she was weaned off parenteral nutrition. She was 4 years and 2 months old at the last visit in the outpatient clinic, and she had an improved nutrition status (body weight $14.4 \mathrm{~kg}$, height $95.0 \mathrm{~cm}$,
WAZ -0.92, WHZ 0.40, HAZ -1.97) with no signs of symptom recurrence. The pedigree of the proband's family was shown in Fig. 3a. The growth curve was shown in Fig. 3b, Fig. 3c, and Fig. 3d. Albumin and immunoglobins remained in the normal range without the requirement of extra infusion. She had a normal TG level under a fat-restricted diet. IGF-1 and IGF BP-3 also

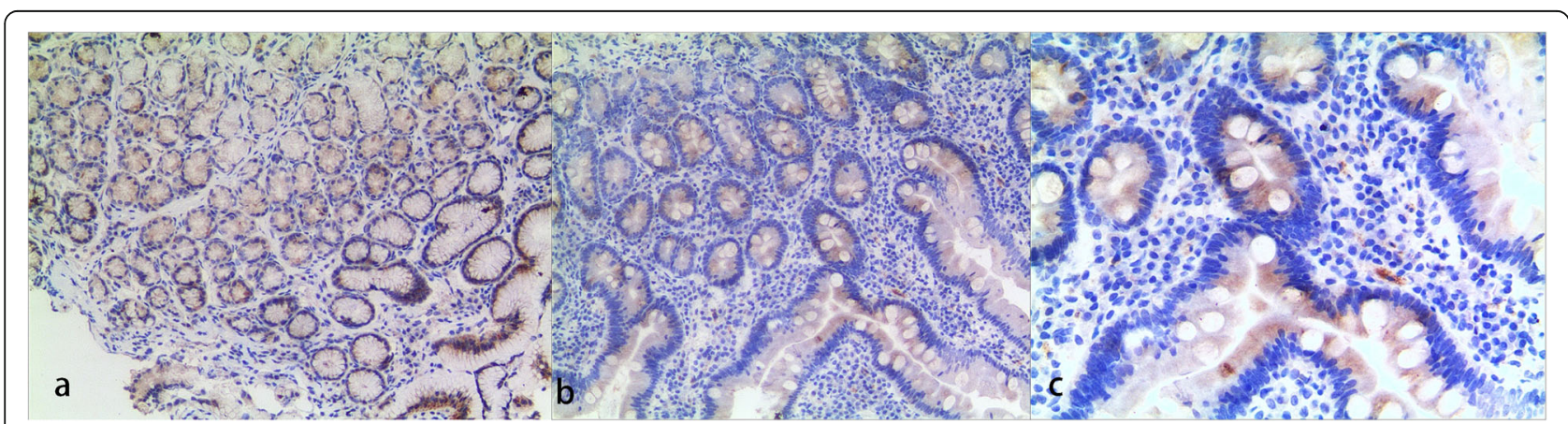

Fig. 2 DGAT1 protein expression in the proband. a Immunohistochemistry of DGAT1 in the proband's biopsy of the gastric antrum $(\times 100)$. b Immunohistochemistry of DGAT1 in the proband's biopsy at the duodenum $(\times 100)$. c Immunohistochemistry of DGAT1 in the proband's biopsy at the duodenum $(\times 200)$ 


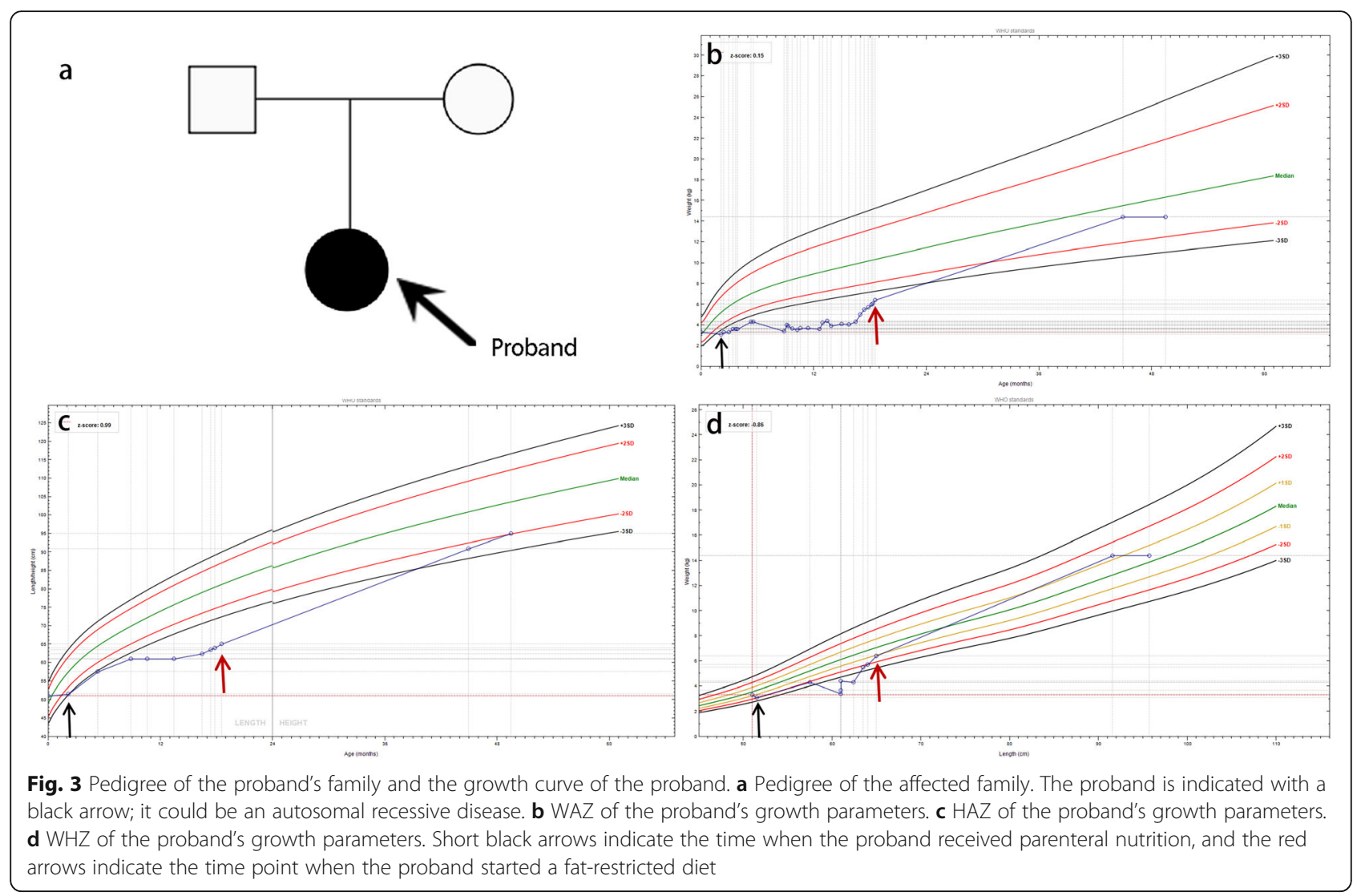

returned to the normal range. Her parents were satisfied with this result.

\section{Discussion and conclusions}

Fat is the main energy source for infants, and lipid metabolism widely exists in the human body, not only in different systems but also in different kinds of cells. DGAT1 plays an important role in TG synthesis [3]. Thus, theoretically, mutations in DGAT1 can cause variant symptoms not only related to lipid absorption but also related to dysfunction of multiple organs. Human intestines may be more sensitive to DGAT1 mutations because of the lack of expression of DGAT2 [4]. Recent studies $[4-8,14]$ (Table 1) showed mutations in DGAT1 from a total of 23 patients are linked to PLE with failure to thrive. These studies revealed that DGAT1 mutations can lead to early-onset, chronic and intractable diarrhoea, which may develop into intestinal failure. In contrast with previously reported cases, our patient had diarrhoea until 8 months after birth despite her hypertriglyceridemia occurring in early infancy. This might have contributed to her compound heterozygous mutations in DGAT1. Another important symptom of patients with DGAT1 mutations is vomiting. Our patient also had vomiting, which was similar to the reported 12 patients $[4,7,8]$. A previous study [15] may explain the potential reason: intestinal DGAT1 deficiency inhibits chylomicron secretion and delays gastric emptying. Other clinical characteristics that our patient had, such as failure to thrive, hypoalbuminemia, and decreased serum immunoglobins, have also described in previous studies [4-8].

Mutations in DGAT1 leading to protein expression deletion or downregulation are still controversial. One study [7] revealed that some DGAT1 mutations can cause a lack of DGAT1 protein expression in the human epithelial cells of the duodenum, ileum, colon, patientderived fibroblasts, Epstein-Barr virus-derived Blymphoblastic cell lines and patient-derived intestinal organoids. In addition, another two studies $[5,6]$ revealed that some mutations in DGAT1 can cause partial function loss, which leads to decreased expression in patients' dermal fibroblasts. The differences may be due to the different locations of the mutation in the DGAT1 gene. Further functional analysis of mutated alleles is needed to obtain a better understanding of the genotype-phenotype relationships in DGAT1 mutation patients.

The DGAT1 mutations in our patient were two compound mutational sites in the DGAT1 exon region, which were located in splice sites and probably affected the function of the protein. They were likely pathogenic. 
Table 1 Characteristics of published DGAT1 deficiency patients

\begin{tabular}{|c|c|c|c|c|c|c|}
\hline Patient & Descent & $\begin{array}{l}\text { Onset } \\
\text { age }\end{array}$ & Features & Nutrition support & Other Treatment & Outcome \\
\hline $\begin{array}{l}\text { Patient } \\
1[4]\end{array}$ & $\begin{array}{l}\text { Ashkenazi } \\
\text { Jewish }\end{array}$ & $\begin{array}{l}0.1 \\
\text { month }\end{array}$ & $\begin{array}{l}\text { vomiting, diarrhoea, malnutrition, } \\
\text { hypertriglyceridemia, hypoalbuminemia }\end{array}$ & $\begin{array}{l}\text { TPN, gastrostomy tube feeding } \\
\text { with amino acid-based formula }\end{array}$ & albumin infusion & died \\
\hline $\begin{array}{l}\text { Patient } \\
2[4]\end{array}$ & $\begin{array}{l}\text { Ashkenazi } \\
\text { Jewish }\end{array}$ & $\begin{array}{l}0.1 \\
\text { month }\end{array}$ & $\begin{array}{l}\text { diarrhoea, hypertriglyceridemia, } \\
\text { hypoalbuminemia }\end{array}$ & $\begin{array}{l}\text { TPN and amino acid-based for- } \\
\text { mula feeding }\end{array}$ & $\begin{array}{l}\text { albumin infusion, } \\
\text { cholestyramin }\end{array}$ & $\begin{array}{l}\text { thrived at } 46 \text { months of age on } \\
\text { an unrestricted diet }\end{array}$ \\
\hline $\begin{array}{l}\text { Patient } \\
3[5]\end{array}$ & $\begin{array}{l}\text { Arab- } \\
\text { Muslim }\end{array}$ & $\begin{array}{l}2 \\
\text { months }\end{array}$ & $\begin{array}{l}\text { diarrhoea, extremity edema, cachectic } \\
\text { with FTT, hypertriglyceridemia, } \\
\text { hypoalbuminemia }\end{array}$ & $\begin{array}{l}\text { amino acid-based formula feed- } \\
\text { ing, later with PN and Monogen } \\
\text { formula }\end{array}$ & $\begin{array}{l}\text { albumin and IVIG } \\
\text { infusion, metronidazole } \\
\text { infusion }\end{array}$ & $\begin{array}{l}\text { discharged home without } \\
\text { diarrhoea }\end{array}$ \\
\hline $\begin{array}{l}\text { Patient } \\
4[5]\end{array}$ & $\begin{array}{l}\text { Arab- } \\
\text { Muslim }\end{array}$ & NM & $\begin{array}{l}\text { diarrhoea, edema, weight loss and skin } \\
\text { abscesses }\end{array}$ & NM & NM & died \\
\hline $\begin{array}{l}\text { Patient } \\
5[5]\end{array}$ & $\begin{array}{l}\text { Ashkenazi } \\
\text { Jewish }\end{array}$ & $\begin{array}{l}0.27 \\
\text { months }\end{array}$ & diarrhoea, FTT, edema, hypotonia & $\begin{array}{l}\text { TPN and amino acid-based for- } \\
\text { mula feeding }\end{array}$ & $\begin{array}{l}\text { chicken soup formula } \\
\text { mixed with rice water } \\
\text { and ORS }\end{array}$ & $\begin{array}{l}\text { improved on a regular diet } \\
\text { except for dairy products }\end{array}$ \\
\hline $\begin{array}{l}\text { Patient } \\
6[5]\end{array}$ & $\begin{array}{l}\text { Ashkenazi } \\
\text { Jewish }\end{array}$ & $\begin{array}{l}\text { sooner } \\
\text { after } \\
\text { birth }\end{array}$ & diarrhoea, hypertriglyceridemia & TPN & $\begin{array}{l}\text { chicken soup formula } \\
\text { mixed with rice water } \\
\text { and ORS }\end{array}$ & $\begin{array}{l}\text { maintained his weight albumin } \\
\text { on enteral feeding }\end{array}$ \\
\hline $\begin{array}{l}\text { Patient } \\
7[5]\end{array}$ & NM & NM & NM & NM & NM & NM \\
\hline $\begin{array}{l}\text { Patient } \\
8[5]\end{array}$ & NM & NM & NM & NM & NM & NM \\
\hline $\begin{array}{l}\text { Patient } \\
9[6]\end{array}$ & $\begin{array}{l}\text { South } \\
\text { Asian }\end{array}$ & $\begin{array}{l}\text { shortly } \\
\text { after } \\
\text { birth }\end{array}$ & diarrhoea, FTT, hypertriglyceridemia & $\begin{array}{l}\text { PN, gastrostomy tube feeding } \\
\text { with a hydrolyzed formula }\end{array}$ & $\begin{array}{l}\text { blood cell transfusion, } \\
\text { IVIG }\end{array}$ & $\begin{array}{l}\text { transitioned to a diet containing } \\
\text { no more than } 10 \% \text { calories from } \\
\text { fat }\end{array}$ \\
\hline $\begin{array}{l}\text { Patient } \\
10[6]\end{array}$ & $\begin{array}{l}\text { South } \\
\text { Asian }\end{array}$ & $\begin{array}{l}\text { shortly } \\
\text { after } \\
\text { birth }\end{array}$ & diarrhoea & NM & NM & $\begin{array}{l}\text { improved on a very low fat } \\
\text { enteral diet. }\end{array}$ \\
\hline $\begin{array}{l}\text { Patient } \\
11[7]\end{array}$ & Turkish & birth & $\begin{array}{l}\text { vomiting, diarrhoea, FTT, } \\
\text { hypoalbuminemia }\end{array}$ & Fat-free fomula and MCT & albumin infusion & $\begin{array}{l}\text { no diarrhoea and normal growth } \\
\text { with low-fat diet }+\mathrm{MCT}+\text { fat-free } \\
\text { formula }\end{array}$ \\
\hline $\begin{array}{l}\text { Patient } \\
12[7]\end{array}$ & Turkish & birth & $\begin{array}{l}\text { vomiting, diarrhoea, } \mathrm{FTT} \text {, } \\
\text { hypoalbuminemia }\end{array}$ & NM & albumin infusion & died \\
\hline $\begin{array}{l}\text { Patient } \\
13[7]\end{array}$ & Turkish & $\begin{array}{l}0.75 \\
\text { months }\end{array}$ & $\begin{array}{l}\text { vomiting, diarrhoea, FTT, } \\
\text { hypertriglyceridemia, hypoalbuminemia }\end{array}$ & TPN & albumin infusion & $\begin{array}{l}\text { diarrhoea improved with basic } \\
\text { formula feeding }\end{array}$ \\
\hline $\begin{array}{l}\text { Patient } \\
14[7]\end{array}$ & Turkish & $\begin{array}{l}2 \\
\text { months }\end{array}$ & $\begin{array}{l}\text { vomiting, diarrhoea, FTT, } \\
\text { hypoalbuminemia }\end{array}$ & NM & cholestyramine & diarrhoea improved \\
\hline $\begin{array}{l}\text { Patient } \\
15[7]\end{array}$ & Turkish & $\begin{array}{l}1.3 \\
\text { months }\end{array}$ & $\begin{array}{l}\text { vomiting, diarrhoea, FTT, } \\
\text { hypoalbuminemia }\end{array}$ & hydrolyzed formula & Creon pancreatic lipase & $\begin{array}{l}\text { diarrhoea improved but } \\
\text { remained malnutrition }\end{array}$ \\
\hline $\begin{array}{l}\text { Patient } \\
16[7]\end{array}$ & Turkish & $\begin{array}{l}2.5 \\
\text { months }\end{array}$ & vomiting, diarrhoea, FTT & NM & Creon pancreatic lipase & diarrhoea improved \\
\hline $\begin{array}{l}\text { Patient } \\
17[7]\end{array}$ & Caucasian & 1 & vomiting & $\begin{array}{l}\text { infusion of Intralipid and } \\
\text { Omegaven suppletion of lipid } \\
\text { soluble vitamins }\end{array}$ & NM & enteral feeding without fat \\
\hline $\begin{array}{l}\text { Patient } \\
18[7]\end{array}$ & Caucasian & $\begin{array}{l}1 \\
\text { month }\end{array}$ & vomiting, FTT & $\begin{array}{l}\text { infusion of Intralipid and } \\
\text { Omegaven suppletion of lipid } \\
\text { soluble vitamins }\end{array}$ & NM & enteral feeding without fat \\
\hline $\begin{array}{l}\text { Patient } \\
19[7]\end{array}$ & Caucasian & birth & $\begin{array}{l}\text { vomiting, diarrhoea, } \mathrm{FTT} \text {, } \\
\text { hypoalbuminemia }\end{array}$ & TPN & $\begin{array}{l}\text { small bowel } \\
\text { transplantation }\end{array}$ & still stunted \\
\hline $\begin{array}{l}\text { Patient } \\
20[7]\end{array}$ & Caucasian & birth & $\begin{array}{l}\text { vomiting, diarrhoea, FTT, } \\
\text { hypoalbuminemia }\end{array}$ & TPN, fat-free formula & NM & still stunted \\
\hline $\begin{array}{l}\text { Patient } \\
21[8]\end{array}$ & Caucasian & $\begin{array}{l}1 \\
\text { month }\end{array}$ & $\begin{array}{l}\text { vomiting, diarrhoea, malnutrition, } \\
\text { hypoalbuminemia }\end{array}$ & $\begin{array}{l}\text { TPN, nasojejunal tube feeding } \\
\text { with amino acid-based formula }\end{array}$ & antibiotics & improved on a low-fat diet \\
\hline $\begin{array}{l}\text { Patient } \\
22[14]\end{array}$ & Chinese & birth & vomiting, watery diarrhoea & TPN & $\begin{array}{l}\text { albumin and IVIG } \\
\text { infusion }\end{array}$ & died \\
\hline $\begin{array}{l}\text { Patient } \\
23[14]\end{array}$ & Chinese & birth & edema,watery diarrhoea & TPN, enteral nutrition & $\begin{array}{l}\text { albumin and IVIG } \\
\text { infusion }\end{array}$ & died \\
\hline
\end{tabular}

TPN Total parenteral nutrition, PN Parenteral nutrition, IVIG Intravenous immune globulin, NM Not mentioned, FTT Failure to thrive, MCT Medium-chain triglyceride, ORS Oral rehydration solution

The patient's clinical characteristics and immunohistochemical results of the duodenum were also in line with the pathogenicity of such compound heterozygous mutations. To date, several homozygous mutations have already been identified in Turkish Caucasians in the Netherlands and South Asian, Ashkenazi Jew, Arab- 
Muslim, and Chinese populations [4-7, 14]. There is one case of compound heterozygous mutations in Caucasians [8]. This is the first described compound heterozygous mutation in the Chinese population.

How the variant mutations in DGAT1 are linked to such critical disease remains unknown. One [7] of those studies explored the possible molecular pathomechanism: lipotoxicity in the intestinal epithelium accompanied by DGAT1 deficiency leads to mucosal injury, which developed clinical features of PLE. However, to date, those reported patients had variant onset ages of different symptoms. Further investigation will be needed to explore the deeper mechanism. Autophagy or endoplasmic reticulum stress is also possibly involved in this process and has already been implicated in other lipid metabolic disorders [16].

For the early diagnosis of this disease, patients usually show signs of PLE with failure to thrive in early infancy, but delayed intractable diarrhoea is also one of the clinical characteristics. The faecal elastase level is not a specific indicator [7] but can be used to rule out some other diseases with similar symptoms. The faecal alpha1-antitrypsin level is helpful to establish the diagnosis of PLE [17]. Although DGAT1 mutations affect lipid metabolism, not all patients have hypertriglyceridemia [5-7]. Including our patient, 7 in 24 patients [5-8] were reported to have hypertriglyceridemia. Unexplained hypertriglyceridemia in early life may be a strong indicator of lipid metabolic disorder. Patients always have a failure to thrive with extremely poor nutrition status, but prealbumin may be at a normal level as in our patient. In PLE patients, albumin synthesis increases while enteric albumin is lost [18], and the body cannot compensate completely [19]. Thus, proteins with longer half-lives, such as albumin and immunoglobulins, are affected, but proteins with shorter half-lives, such as prealbumin, are less affected. In our patient, IGF-1 and IGFBP-3 both decreased in the early clinical course and reversed to normal levels during the follow-up when her nutrition status improved. This indicates that IGF-1 and IGFBP-3 change secondary to malnutrition, which is consistent with some previous findings [20,21]. Most of the patients $[4,5,7]$, including our patient, have recurrent infections. This may be due to decreased immunoglobin levels secondary to malnutrition and long-term use of central lines.

Nutrition therapy with a fat-restricted diet is an effective way to manage these patients. When reviewing diet changes in 16 surviving patients, 9 patients showed a good response to a low-fat diet (Table 1). One of them transitioned to a regular diet, and the remaining 8 patients were still on a low-fat diet [6-8]. One study [6] reported that the patient had a diet in which fat supplied less than $10 \%$ calories. Our patient showed great improvement after a fat-restricted diet was introduced. Since an analysis [22] says that approximately $95-98 \%$ of breast milk fat is TG, breastfeeding may not be a good choice for babies with DGAT1 deficiency. The patient reported here also showed intolerance of breastfeeding. Parenteral nutrition plays an important role even when the exact aetiology is unclear. When the genetic test and immunohistochemical results confirm the diagnosis, the transition to a fat-restricted diet will still need parental nutrition to provide essential fatty acids and fat-soluble vitamins. Thus, occasional infusion of lipid emulsion with fat-soluble vitamins is necessary [7]. In our experience, early intervention with parenteral nutrition prevents fat-soluble vitamin deficiency despite the unclear aetiology. Our patient tolerated a maximum dose of 3.8 $\mathrm{g} / \mathrm{kg} / \mathrm{d}$ lipid emulsion without lipid clearance problems. Parental nutrition lasting for 11 months was safe, but body weight gain remained poor, which might be due to the DGAT1 deficiency mediating lipid metabolic disorders. Fat-soluble vitamins, such as vitamin A and vitamin $\mathrm{D}$, were maintained in the normal range even when parenteral nutrition stopped as she was discharged. Quality of life and prevention of infections should also be the physician's concerns.

In summary, we reported a patient with DGAT1 compound heterozygous mutations in the Chinese population who presented delayed chronic diarrhoea. This case expanded our knowledge of the clinical features of patients with DGAT1 mutations. Paediatricians should be alert to this disease when infants have delayed intractable diarrhoea with failure to thrive. We had only one case here, and more studies focusing on the mechanism of lipid metabolism in DGAT1-deficient patients will be necessary in the future.

\section{Supplementary Information}

The online version contains supplementary material available at https://doi. org/10.1186/s12881-020-01164-1.

Additional file 1. Description of immunohistochemical analysis.

Additional file 2. Immunohistochemistry of DGAT1 in the duodenum.

\section{Abbreviations}

DGAT1: Diacylglycerol o-acyltransferase 1; TG: Triglyceride; DAG: Diacylglycerol; PLE: Protein-losing enteropathy;

IHC: Immunohistochemistry; IGF-1: Insulin-like growth factor-1; IGF BP3: Insulin-like growth factor binding protein-3; WAZ: Weight-for-age z-score; HAZ: Length/height-for-age z-score; WHZ: Weight-for-length z-score; WES: Whole-exome sequencing

\section{Acknowledgments}

We thank Mrs. Lili Yang who is the deputy managing editor of World Journal of Paediatrics for her precious advice. We also thank Mr. Wei Ding from Running Gene Inc. for his effort on gene analysis.

\section{Authors' contributions}

$L X, Y L, J L$, and $J C$ designed the research. $Y L$ and $J L$ conducted the research; WG performed the histological and immunohistochemical examination of 
the specimen. $L X$ and $Y L$ collected the data. $L X$ analyzed the data. JC checked all of the data. LX was a major contributor in writing the manuscript. JC had primary responsibility for the final content. The authors offered critical comments, read and approved the final manuscript.

\section{Funding}

No funding.

\section{Availability of data and materials}

WES data of the proband were deposited in the NCBI Sequence Read Archive (SRA) database (Project ID: PRJNA673384). All datasets generated or analysed during the current study are included in this published article and available from the corresponding author on reasonable request. Database analysed in the study included gnomAD (gnomad.broadinstitute.org).

\section{Ethics approval and consent to participate}

The Ethics Committee of Children's Hospital Zhejiang University School of Medicine approved this study (No.2018-IRB-059 and 2019-IRB-001). All procedures performed in this study involving human participants were in accordance with the ethical standards of the institutional and/or national research committee and with the 1964 Helsinki declaration and its later amendments or comparable ethical standards. Written consent was obtained from the parents of the proband for the collection of samples and for DNA sequencing.

\section{Consent for publication}

Written informed consent for publication of identifying images or the clinical details was obtained from the parents or legal guardians of any participant under the age 18 .

\section{Competing interests}

The authors declare that they have no competing interests.

\section{Author details}

'Present Address: Department of Gastroenterology, Children's Hospital, Zhejiang University School of Medicine, National Clinical Research Center for Child Health, No.3333, Binsheng Road, Hangzhou, Zhejiang Province, PR China. ${ }^{2}$ Present Address: Department of Pathology, Children's Hospital, Zhejiang University School of Medicine, National Clinical Research Center for Child Health, No.3333, Binsheng Road, Hangzhou, Zhejiang Province, PR China.

Received: 7 May 2019 Accepted: 4 November 2020

Published online: 01 December 2020

\section{References}

1. Thiagarajah JR, Kamin DS, Acra S, Goldsmith JD, Roland JT, Lencer WI, et al. Advances in evaluation of chronic diarrhea in infants. Gastroenterology. 2018;154(8):2045-59

2. Cases S, Smith SJ, Zheng YW, Myers HM, Lear SR, Sande E, et al. Identification of a gene encoding an acyl CoA:diacylglycerol acyltransferase, a key enzyme in triacylglycerol synthesis. Proc Natl Acad Sci. 1998;95(22): $13018-23$.

3. Yan CL, Stone SJ, Koliwad S, Harris C, Farese RV. Thematic review series: glycerolipids. DGAT enzyme and triacylglycerol biosynthesis. J Lipid Res. 2008;49(11):2283-301.

4. Haas JT, Winter HS, Lim E, Kirby A, Blumenstiel B, DeFelice M, et al. DGAT1 mutation is linked to a congenital diarrheal disorder. J Clin Invest. 2012; 122(12):4680-4.

5. Stephen J, Vilboux T, Haberman Y, Pri-Chen H, Pode-Shakked B, Mazaheri S, et al. Congenital protein losing enteropathy: an inborn error of lipid metabolism due to DGAT1 mutations. Eur J Hum Genet. 2016;24(9):1268-73.

6. Gluchowski NL, Chitraju C, Picoraro JA, Mejhert N, Pinto S, Xin W, et al. Identification and characterization of a novel DGAT1 missense mutation associated with congenital diarrhea. J Lipid Res. 2017;58(6):1230-7.

7. van Rijn JM, Ardy RC, Kuloğlu Z, Härter B, van Haaften-Visser DY, van der Doef HPJ, et al. Intestinal failure and aberrant lipid metabolism in patients with DGAT1Deficiency. Gastroenterology. 2018;155(1):130-143.e15.

8. Ratchford TL, Kirby AJ, Pinz H, Patel DR. Congenital diarrhea from DGAT1 mutation leading to electrolyte derangements, protein-losing Enteropathy, and rickets. J Pediatr Gastroenterol Nutr. 2018;66(3):e82-3.
9. Fang Y, Luo Y, Yu J, Lou J, Chen J. Phenotypic and genotypic characterization of inflammatory bowel disease in children under six years of age in China. World J Gastroenterol. 2018;24(9):1035-45.

10. GnomAD database.gnomad.broadinstitute.org Accessed 15 Dec 2019.

11. Davydov EV, Goode DL, Sirota M, Cooper GM, Sidow A, Batzoglou S. Identifying a high fraction of the human genome to be under selective constraint using GERP++. PLoS Comput Biol. 2010;6(12):e1001025.

12. Schwarz JM, Cooper DN, Schuelke M, Seelow D. MutationTaster2: mutation prediction for the deep-sequencing age. Nat Methods. 2014;11(4):361-2.

13. Desmet FO, Hamroun D, Lalande M, Collod-Béroud G, Claustres M, Béroud C. Human splicing finder: an online bioinformatics tool to predict splicing signals. Nucleic Acids Res. 2009;37(9):e67.

14. Ye Z, Huang Y, Zheng C, Wang Y, Lu J, Wang H, et al. Clinical and genetic spectrum of children with congenital diarrhea and enteropathy in China. Genet Med. 2019:21(10):2224-30.

15. Ables GP, Yang KJ, Vogel S, Hernadez-Ono A, Yu S, Yuen JJ, et al. Intestinal DGAT1 deficiency reduces postprandial triglyceride and retinyl ester excursions by inhibiting chylomicron secretion and delaying gastric emptying. J Lipid Res. 2012;53(11):2364-79.

16. Schwerd T, Pandey S, Yang HT, Bagola K, Jameson E, Jung J, et al. Impaired antibacterial autophagy links granulomatous intestinal inflammation in Niemann-pick disease type C1 and XIAP deficiency with NOD2 variants in Crohn's disease. Gut. 2017;66(6):1060-73.

17. Braamskamp MJ, Dolman KM, Tabbers MM. Clinical practice. Protein-losing enteropathy in children. Eur J Pediatr. 2010;169(10):1179-85.

18. Takeda H, Ishihama K, Fukui T, Fujishima S, Orii T, Nakazawa Y, et al. Significance of rapid turnover proteins in protein-losinggastroenteropathy. Hepatogastroenterology. 2003;50(54):1963-5.

19. Wochner RD, Weismann SM, Waldmann TA, Houston D, Berlin NI. Direct measurement of the rates of synthesis of plasma proteins in control subjects and patients with gastrointestinal protein loss. J Clin Invest. 1968; 47:971-82.

20. Lee SE, Stewart CP, Schulze KJ, Cole RN, Wu LS, Yager JD, et al. The plasma proteome is associated with anthropometric status of undernourished Nepalese school-aged children. J Nutr. 2017;147(3):304-13.

21. Syed S, Manji KP, McDonald CM, Kisenge R, Aboud S, Sudfeld C, et al. Biomarkers of systemic inflammation and growth in early infancy are associated with stunting in young Tanzanian children. Nutrients. 2018;10(9): 1158.

22. Prentice P, Ong KK, Schoemaker MH, van Tol EA, Vervoort J, Hughes IA, et al. Breast milk nutrient content and infancy growth. ActaPaediatr. 2016; 105(6):641-7.

\section{Publisher's Note}

Springer Nature remains neutral with regard to jurisdictional claims in published maps and institutional affiliations.

Ready to submit your research? Choose BMC and benefit from:

- fast, convenient online submission

- thorough peer review by experienced researchers in your field

- rapid publication on acceptance

- support for research data, including large and complex data types

- gold Open Access which fosters wider collaboration and increased citations

- maximum visibility for your research: over $100 \mathrm{M}$ website views per year

At $\mathrm{BMC}$, research is always in progress.

Learn more biomedcentral.com/submission 